\title{
The Brain Kv1.1 Potassium Channel: In vitro and in vivo Studies on Subunit Assembly and Posttranslational Processing
}

\author{
Karen K. Deal,' David M. Lovinger, ${ }^{1,2}$ and Michael M. Tamkun ${ }^{1,2}$

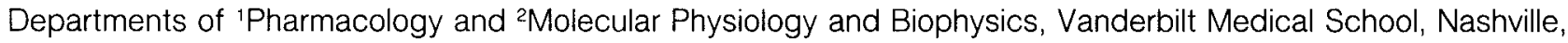 \\ Tennessee 37232
}

While combined cloning, mutagenesis, and electrophysiological techniques have provided great insight into $\mathrm{K}^{+}$channel structure/function relationships, little is known about $\mathbf{K}^{+}$ channel biosynthesis. To examine $\mathrm{K}^{+}$channel biosynthesis, immune purifications were conducted on Triton $X-100$ extracts of ${ }^{35} \mathrm{~S}-\mathrm{met}-\mathrm{labeled}$ channels from in vitro translations and transfected mouse L-cells. When Kv1.1 and Kv1.4 were cotranslated in vitro, isoform-specific antisera copurified both proteins even at early time points, suggesting rapid subunit assembly. The non-Shaker Kv2.1 channel did not assemble with Kv1.1 or Kv1.4. Mouse L-cells transfected with Kv1.1 cDNA yielded 1000-4000 functional surface channels, and immune purification from Kv1.1 cells with Kv1.1 antisera produced a 57-59 kDa doublet on SDS-PAGE but not in shamtransfected cells. Immune purification of surface channels isolated both the 57 and $59 \mathrm{kDa}$ proteins, suggesting cell surface channels are represented by two species. Pulsechase metabolic labeling studies were consistent with a precursor-product relationship with the $57 \mathrm{kDa}$ species giving rise to the $59 \mathrm{kDa}$ protein within several minutes of synthesis. At longer chase times, the 57 kDa species reappeared, indicating both an early precursor and a mature protein ran with identical electrophoretic mobility. Mutation of the extracellular glycosylation site (N207) yielded two proteins at steady state, a $55 \mathrm{kDa}$ core peptide and a $57 \mathrm{kDa}$ species. Lack of glycosylation at N207 had little effect on channel synthesis, turnover, or function. Together these results suggest (1) heteromeric assembly of Shaker-like channels is cotranslational, and (2) N207 glycosylation of Kv1.1 occurs but is not required for subunit assembly, transport, or function.

[Key words: potassium channel biosynthesis, heteromeric assembly, glycosylation, immune purification]

Our understanding of voltage-gated $\mathrm{K}^{+}$channels has grown exponentially during the past decade. To date, multiple $\mathrm{K}^{+}$channel gene families have been defined, from which in excess of 25 $\mathrm{K}^{+}$channels have been cloned and functionally expressed in

\footnotetext{
Received June 2, 1993; revised July 30, 1993; accepted Aug. 26, 1993.

We thank Drs. Lee Limbird, Al George, and Jeffrey Keefer for review of the manuscript. This work was supported by National Institutes of Health Grants HL49330 (M.M.T.) and NS30470 (D.M.L.) M.M.T. is an Established Investigator of the American Heart Association. K.K.D. was supported by Medical Scientist Training Program Grant GM07347.

Correspondence should be addressed to Michael M. Tamkun, Department of Molecular Physiology and Biophysics, Vanderbilt University Medical School, Nashville, TN 37232 .

Copyright (C) 1994 Society for Neuroscience $0270-6474 / 94 / 141666-11 \$ 05.00 / 0$
}

heterologous expression systems. The mammalian $\mathrm{Kvl}$ family is the largest and is homologous to the original Drosophila Shaker channel (Papazian et al., 1987; Tempel et al., 1987; Pongs et al., 1988). The Kv2, Kv3, and Kv4 mammalian families are homologous to the Drosophila Shab, Shaw, and Shal channels, respectively (Frech et al., 1989; Swanson et al., 1990; Roberds and Tamkun, 1991). Two other Drosophila families are represented by the Slowpoke $\mathrm{Ca}^{2+}$-activated $\mathrm{K}^{+}$channel (Slo; Atkinson et al., 1991) and the ether-a-go-go channel (eag; Warmke et al., 1991). The slow delayed rectifier, $I_{\mathrm{sk}}$ (Takumi et al., 1988), the mammalian inward rectifier (Kubo et al., 1993), and ATPsensitive channels (Ho et al., 1993) have been cloned by expression methods, adding three more gene families. With the exception of the gene products of these latter three families, all known voltage-gated $\mathrm{K}^{+}$channels have six putative membranespanning domains, with the fourth domain (S4) being arginineand lysinc-rich and contributing to the voltage-sensing function of the protein (Papazian et al., 1991). Structure/function studies also have identified amino acids involved in ion selectivity (Yool and Schwartz, 1991; Heginbotham, 1992), inactivation (Hoshi et al., 1990), and neurotoxin binding (MacKinnon and Miller, 1989). Members of the $I_{\mathrm{sK}}$ family of voltage-gated $\mathrm{K}^{+}$channels possess only a single predicted membrane-spanning domain (Philipson and Miller, 1992), while the inward rectifier (Kubo et al., 1993) and ATP-sensitive $\mathrm{K}^{+}$channels (Ho et al., 1993) have two postulated membrane spanning domains. Whether the channels containing one or two membrane-spanning domains form homomultimers is yet unknown. However, in the case of the $\mathrm{K}^{+}$channels with six transmembrane domains, four individual subunits coassemble to form functional channels (MacKinnon, 1991), and expression studies suggest that no additional proteins are required for voltage-sensitive $\mathrm{K}^{+}$transport (Timpe et al., 1988). Different isoforms within the Kvl subfamily can assemble to form functional heterotetramers with properties intermediate of those characteristic of the corresponding homotetramers (Christie et al., 1990; Isacoff et al., 1990; Ruppersberg et al., 1990). This heterotetrameric assembly provides for an even greater level of $\mathrm{K}^{+}$channel diversity than that made possible by the number of genes identified thus far.

While the integration of electrophysiological and site-directed mutagenesis techniques has provided great insight in to the structure/function relationship of various protein domains and amino acids, the study of $\mathrm{K}^{+}$channel biosynthesis, subunit assembly, and processing is in its infancy. However, at least one domain involved in channel subunit assembly has been identified ( $\mathrm{Li}$ et al., 1992), and the ability of subunits to functionally assemble in in vitro translation extracts has been demonstrated (Rosenberg and East, 1992). The present study represents the first 
description of the biosynthesis and posttranslational processing of a voltage-gated $\mathrm{K}^{+}$channel in a heterologous expression system.

The primary channel chosen for this work was originally cloned from rat brain as RCK1 (Baumann et al., 1988) and RBK1 (Christie et al., 1989) and from rat aorta as RKI (Roberds and Tamkun, 1991). Under the universal nomenclature (Chandy, 1991) this channel is defined as Kv1.1 since it is homologous to the Drosophila Shaker family of $\mathrm{K}^{+}$channels. mRNA encoding this channel is most abundant in brain and much less abundant in cardiac and skeletal muscle (Roberds and Tamkun, 1991). The Kv1.1 cDNA predicts a protein of 56,343 molecular weight that spans the membrane six times. Current models predict that both the $\mathrm{N}$ - and C-terminal ends are inside the cell. Expression studies in Xenopus oocytes (Christie et al., 1989) and tissue culture cells (Koren et al., 1990) have determined that this channel is a rapidly activating delayed rectifier with little inactivation at $20^{\circ} \mathrm{C}$. Tandem, trimeric, tetrameric, and pentameric constructs of this channel have been used extensively by several groups to address questions of stoichiometry with sometimes conflicting interpretations (Liman et al., 1992; McCormack et al., 1992).

The other channel investigated in this study is the Kv1.4 channel originally cloned from rat brain as RCK4 (Stuhmer et al., 1989), human ventricle as HK1 (Tamkun et al., 1991), and rat heart as RK3 (Roberds and Tamkun, 1991) and RHK1 (Tseng-Crank et al., 1990). This channel has a predicted molecular weight of 73,211 and the same predicted membrane topology as Kv1.1, and shows moderate amino acid sequence identity with $\mathrm{Kv} 1.1$. Kv1.4 is a rapidly activating and fastinactivating $\mathrm{K}^{+}$channel when expressed in either Xenopus oocytes (Tseng-Crank et al., 1990; Po et al., 1992) or mouse L-cells (Roberds et al., 1993) and can form functional heterotetramers with the Kv1.1 channel (Po et al., 1993).

The findings reported here indicate that the Kv1.1 channel undergoes rapid, complex posttranslational processing. Glycosylation at the single extracellular $\mathrm{N}$-linked consensus site accounts for only one of several processing steps. Heteromeric subunit assembly with Kv1.4 appears to be cotranslational based on findings in in vitro translation experiments. Glycosylation is not required for subunit assembly, transport to the surface, protein stability, or channel function. Cell surface channels are represented by two molecular weight species while the same channel in brain appears as a single species (Wang et al., 1993). Whether this difference between the tissue culture expression system and brain is functionally significant remains to be answered.

\section{Materials and Methods}

Materials. Affinity-purified Kv2.1 antisera raised against a pGEX/Kv2.1 fusion protein were a generous gift from Dr. James Trimmer, State University of New York, Stonybrook. The Kv2.1 cDNA was provided by Dr. Rolf Joho, University of Texas Health Sciences Center, Dallas. Mouse Ltk- (L-cells) were a gift from Dr. Douglas Fambrongh, The Johns Hopkins University. Translation grade ${ }^{35} \mathrm{~S}$-methionine $(1170 \mathrm{Ci}$ / $\mathrm{mmol}, 10 \mathrm{mCi} / \mathrm{ml}$ ) was purchased from New England Nuclear Products (Boston, MA). Trans ${ }^{35} \mathrm{~S}$-label $(1100 \mathrm{Ci} / \mathrm{mmol})$ was purchased from ICN (Irvine, CA). Enzymes and buffers were from New England Biolabs (Beverly, MA) and Boehringer Mannheim (Indianapolis, IN). Protein A cross-linked to Sepharose 4B-CL was oblained from Sigma (St. Louis). All materials whose origins are not specified below are reagent grade. Densitometry analyses utilized the UltraScan Enhanced Laser Densitometer and GelScan XL software (Pharmacia LKB, Sollentuna, Sweden)
Production of antisera. The regions of the Kv1.1 (Roberds and Tamkun, 1991 ) and 1.4 (Tamkun et al., 1991) proteins used for antibody production are shown in Figure $1 A$. The C-terminal region, with the exception of the last three amino acids (TDV), which are common between the two proteins, were chosen for antibody production. This region varies extensively among isoforms and thus isoform-specific antibodies were predicted. The amino acid sequences shown in Figure $1 B$ were linked to the C-termini of bacterially expressed proteins.

Polymerase chain reaction (PCR)-generated C-terminal Kv1.1 cDNA was subcloned into the $\beta$-galactosidase ( $\beta$-gal) fusion protein expression vector pUR 291 (Rüther and Müller-Hill, 1983). PCR-generated C-terminal Kv1.4 cDNA was subcloned into the glutathione S-transferase (GST) fusion protein expression vector pGEX-2T (Pharmacia, Piscataway, NJ). Large-scale production of fusion protein for use as immunogen was as previously described by Marston (1987) for the Kv1.1/ $\beta$ gal protein and as described by Ausubel et al. (1989) for the Kv1.4/ GST protein. Immunogen was injected into New Zealand White female rabbits (Myrtle's Rabbitry, Nashville, $\mathrm{TN}$ ) according to established protocol (Ausubel et al., 1989). Affinity purification of Kv1.1 antibodies was achieved by passing antisera over a $\mathrm{Kv} 1.1 / \mathrm{GST}$ fusion protein column and eluting in $100 \mathrm{~mm}$ glycine, $\mathrm{pH} 2.5$, with subsequent neutralization in $2 \mathrm{M}$ Tris[hydroxymethyl]aminomethane (Tris), pH 8 . Affinity purification of Kv1.4 antibodies was achieved by first passing antisera over a GST column to remove anti-GST antibodies and then passage over, and subsequent elution from, a Kv1.4/GST fusion protein column as just described. The concentrations of the affinity-purified $\mathrm{Kv} 1.1$ and $\mathrm{Kv} 1.4$ antibodies were 154 and $83 \mu \mathrm{g} / \mathrm{ml}$, respectively.

In vitro translation of $K^{+}$channel protein. Templates for in vitro cRNA synthesis were constructed as follows: Kv1.1 (nucleotides -45 to +1548 ) was subcloned into the KpnI site of pGEM7 (Promega, Madison, WI). The construct was linearized with NsiI and cRNA was synthesized with 'I'7 RNA polymerase using a transcription kit (Stratagene, La Jolla, CA). The BstXI-EcoRI fragment of Kv 1.4 (nucleotides 1-2150) was isolated, blunted with the Klenow fragment of DNA polymerase I, and subcloned into the blunted BgIII site of the Melton vector (Krieg and Melton, 1987). The construct was linearized with EcoRI, and cRNA was synthesized with SP6 RNA polymerase using the Stratagene kit. Kv2.1 (Frech et al., 1989) cDNA was subcloned into the EcoRI and NotI sites of pBlueScript SK(-) (Stratagene). The construct was linearized with NotI and cRN $\wedge$ synthesized with T7 RN $\wedge$ polymerase.

In vitro translation of the cRNA utilized a nuclease-treated rabbit reticulocyte lysate kit (Promega) supplemented with canine microsomal membranes (Promega) and translation grade ${ }^{35} \mathrm{~S}$-methionine. Translation reactions (generally $25 \mu$ l total volume) were set up according to the manufacturer. Optimally, 200-400 ng of in vitro synthesized cRNA was added to a $25 \mu \mathrm{l}$ reaction. However, when two different cRNAs were being translated, equal amounts of each cRNA were used, but total cRNA did not exceed $500 \mathrm{ng} / 25 \mu \mathrm{l}$ reaction. Translation reactions were incubated at $30^{\circ} \mathrm{C}$ for $60-90 \mathrm{~min}$ or as indicated; however, no increase in translation products was seen after $60 \mathrm{~min}$. Reactions were stopped at $4^{\circ} \mathrm{C}$. Immune isolations of the in vitro translated proteins were conducted from reactions kept at $4^{\circ} \mathrm{C}$ since freezing significantly reduced the ability to immune isolate the proteins. The presence of microsomes enhanced Kv1.4 synthesis fourfold while no Kv1.1 synthesis was observed in the absence of microsomes. The microsomes used were unable to convert high mannose carbohydrate on the ATPase $\beta$ subunit to the complex form (data not shown), suggesting in vitro synthesized protein was not subject to Golgi processing events.

Immune purification of coassembled $\mathrm{K}^{+}$channel subunits. Five microliters of an in vitro reaction were solubilized by addition of $1 \mathrm{ml}$ of extraction buffer $[1 \% \mathrm{w} / \mathrm{v}$ Triton X-100, $150 \mathrm{~mm} \mathrm{NaCl}, 50 \mathrm{~mm}$ Tris (pH 7.5), 1 mm ethylenediaminetetraacetic acid (EDTA), $0.2 \%$ bovine serum albumin (BSA), $5 \mathrm{~mm}$ phenylmethylsulfonyl fluoride, $2 \mathrm{~mm}$ benzamidine, $5 \mathrm{~mm} N$-ethylmaleimide, and $1 \mathrm{mg} / \mathrm{ml}$ bacitracin (Tamkun and Fambrough, 1986); the last four items are protease inhibitors which were added just prior to use] followed by rocking for $1 \mathrm{hr}$ at room temperature $(\mathrm{RT})$. When two different $\mathrm{K}^{+}$channel proteins were cosynthesized, $10 \mu \mathrm{l}$ of the translation reaction was solubilized. When channels were synthesized separately, $5 \mu \mathrm{l}$ of each reaction was combined in a tube, and $1 \mathrm{ml}$ of extraction buffer was added and solubilized for $1 \mathrm{hr}$. Following solubilization, $8 \mu \mathrm{l}$ of either Kv1.1, Kv1.4, or Kv2.1 affinity-purified antisera was added and incubation at RT continued for $2 \mathrm{hr}$ with rocking. Five microliters of packed Protein A Sepharose beads (Sigma Chemical Co., St. Louis, MO), preincubated in $0.2 \%$ BSA for 1 
$\mathrm{hr}$, were added and the incubation continued for an additional $2 \mathrm{hr}$ at RT. When the incubation was completed, the beads were sedimented at $900 \times g$ for $10 \mathrm{sec}$ and washed $(1 \mathrm{ml} /$ wash $)$ as follows: three washes with $0.5 \% \mathrm{w} / \mathrm{v}$ Triton X-100, $150 \mathrm{~mm} \mathrm{NaCl}, 50 \mathrm{~mm}$ Tris, $\mathrm{pH} 7.5$, and 1 mM EDTA (buffer A); one rapid wash with $0.1 \%$ sodium dodecyl sulfate (SDS), $0.1 \% \mathrm{w} / \mathrm{v}$ Triton X-100, $300 \mathrm{~mm} \mathrm{NaCl}$, and $50 \mathrm{~mm}$ Tris, $\mathrm{pH} 7.5$; one wash with $1 \mathrm{M} \mathrm{NaCl}, 0.5 \% \mathrm{w} / \mathrm{v}$ Triton X-100, and $50 \mathrm{~mm}$ Tris, $\mathrm{pH} 7.5$; two washes with buffer $\mathrm{A}$, and one final wash with unbuffered $1 \%$ Triton X-100. The bound protein was eluted from the beads by boiling for $2 \mathrm{~min}$ in SDS sample buffer and analyzed by SDS gel electrophoresis and fluorographed as previously described (Fambrough and Bayne, 1983).

Expression of native Kv1.1 and the N207Q Kv1.1 glycosylation mutant. The Kvl.1 (nucleotides -45 to +1548 ) fragment was isolated from the pGEM7 vector used for in vitro cRNA synthesis described above and subcloned into the KpnI site of the mammalian expression vector pMSVneo, which confers resistance to neomycin analogs in cells expressing the enzyme (Chung et al., 1988). Transcription of the inserted cDNA is under control of the glucocorticoid-inducible MMTV promotor. Construction of the $\mathrm{N} 207 \mathrm{Q}$ mutant involved subcloning the same Kv1.1 KpnI fragment into a modified version of pBlueScript KS + (all but the DraI, ApaI, and KpnI polylinker sites eliminated) (Stratagene). This construct served as a template for PCR mutagenesis. The $5^{\prime}$ primer overlapped the naturally occurring ClaI site, substituting $\mathrm{C}$ and $A$ residues at nucleotide positions 619 and 621 , respectively, in order to change Asn 207 to Gln. The $3^{\prime}$ primer was downstream from an endogenous BstXI site. The PCR product was sequenced in full, ClaI and BstXI ends generated, and the mutation-containing fragment then exchanged for the original sequence. The resulting N207Q Kv1.1 cDNA was subcloned into the KpnI site of pMSVneo.

Mouse L-cells were maintained in Dulbecco's modified Eagle medium (DMEM; GIBCO/Bethesda Research Labs Life Technologies Inc., Grand Island, NY) containing $10 \%$ horse serum (HS; GIBCO) at $37^{\circ} \mathrm{C}$, under a $5 \% \mathrm{CO}_{2}$ atmosphere. Approximately $2.5 \times 10^{5}$ cells were transfected with $1 \mu \mathrm{g}$ of either the Kv1.1 -containing constructs or pMSVneo vector alone (sham-transfected) using the calcium phosphate isolation method previously described (Takeyasu et al., 1987). After $24 \mathrm{hr}$, selection of transfectants was begun using $500 \mu \mathrm{g} / \mathrm{ml} \mathrm{G} 418$ (GIBCO), a neomycin analog. Discrete foci were harvested with a Pasteur pipette, passed to a 24 -well plate, and maintained in DMEM, 10\% HS containing $250 \mu \mathrm{g} /$ $\mathrm{ml} \mathrm{G} 418$. Total RNA $(4 \mu \mathrm{g})$ from each cell line was subject to Northern analysis as previously described in detail (Tamkun et al., 1991). The cell line of each type expressing the highest level of $\mathrm{K}^{+}$channel mRNA was then used for immune purification and electrophysiological studies.

Electrophysiological recordings. Confluent cultures were treated with $4 \mu \mathrm{M}$ dexamethasone (dex; Sigma) for 16-24 hr prior to analysis. Near steady-state channel levels were achieved with these incubation times. The cells were removed from the dishes with a rubber policeman, leaving the vast majority of cells intact. The cell suspension was maintained at $37^{\circ} \mathrm{C}, 5 \% \mathrm{CO}_{2}$ and analyzed within $30 \mathrm{~min}$ to $4 \mathrm{hr}$. Whole-cell recordings were performed at RT using the Axopatch 200 (Axon Instruments, Foster City, CA) patch-clamp amplifier as previously described (Harrison et al., 1993). Patch pipettes had tip resistances of 2-4 M 2 . Seal resistances were $>5 \mathrm{G} \Omega$ and series resistance was maintained at $<10$ $\mathrm{M} \Omega$ with series resistance compensation of $70-80 \%$. Cells were continuously superfused at $1-2 \mathrm{ml} / \mathrm{min}$ with extracellular medium containing (mM) $150 \mathrm{NaCl}, 5 \mathrm{KCl}, 2.5 \mathrm{CaCl}_{2}, 1 \mathrm{MgCl}_{2}, 10$ HEPES [4-(2-hydroxyethyl)-1-piperazine-ethanesulfonic acid], and 10 D-glucose ( $\mathrm{pH}$ buffered to 7.4 using $\mathrm{NaOH}$; osmolarity adjusted to $340 \mathrm{mmol} / \mathrm{kg}$ using sucrose). The solution in the patch pipette contained (mM) $110 \mathrm{KCl}, 1$ $\mathrm{MgCl}_{2}, 5$ BAPTA [1,2-bis(2-aminophenoxy)ethane- $N, N, N^{\prime}, N^{\prime}$-tetraacetic acid], 10 HEPES; $\mathrm{pH}$ was buffered to 7.2 using $\mathrm{KOH}$ and osmolarity adjusted to $310 \mathrm{mmol} / \mathrm{kg}$ using sucrose.

Currents were low-pass filtered at $5 \mathrm{kHz}(-3 \mathrm{~dB}$; Bessel filter), sampled and digitized with a TL-1-125 A/D interface (Axon Instruments), and stored for off-line analysis. Voltage commands, data acquisition, and data analysis were performed using pCLAMP software (Axon Instruments). For measurement of current-voltage $(I / V)$ relationships, cell membrane potential was held at $-80 \mathrm{mV}$ and $250 \mathrm{msec}$ steps were delivered every $2 \mathrm{sec}$ in $10 \mathrm{mV}$ increments to potentials in the range from -100 to $+50 \mathrm{mV}$. The peak current activated during each voltagestep was measured using a cursor-based system. Current values were leak subtracted by measuring current produced by hyperpolarizing potentials, linear extrapolation to more depolarized potentials, and subtraction of leak values from total measured current. All numerical values for current presented in text and figures have been leak subtracted. However, leak subtraction was not performed on current tracings. The reversal potential, $E_{R}$, for Kvl.1-mediated current was measured using peak chord conductance values $(g)$; values at each potential were calculated from the peak currents as $g=I /\left(V_{\text {test }}-E_{R}\right)$. Activation curves were then fitted using the equation $g=g_{\max } / 1+\exp \left[\left(V_{h}-V_{\text {test }}\right) / k\right]$, where $g_{\max }$ is the maximum conductance, $V_{h}$ is the voltage at which current is half-activated, and $k$ is a factor describing the slope of the activation curve.

Metabolic labeling and immune purification of the Kv1.1 and N207Q Kv1.1 channels. Confluent cell cultures (60 mm dish) of Kv1.1-, N207Q

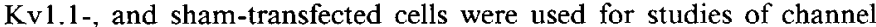
biosynthesis and processing. Trans $\mathrm{s}^{35} \mathrm{~S}$-label (containing approximately $80 \%{ }^{35} \mathrm{~S}$-methionine and $20 \%{ }^{35} \mathrm{~S}$-cysteine) was added to cysteine- and methioninc-deficient media (ICN Biomedicals, Inc.) supplemented with $10 \% \mathrm{HS}, 2.3 \mathrm{mg} / \mathrm{ml}$ glutamine, $250 \mu \mathrm{g} / \mathrm{ml} \mathrm{G} 418$, and $4 \mu \mathrm{M}$ dex. Specific labeling conditions are presented in the figure captions. In general, 200$300 \mu \mathrm{Ci} / \mathrm{ml}$ (calculated only on basis of ${ }^{35} \mathrm{~S}$-methionine) was used for labeling periods in excess of $12 \mathrm{hr}$. Chase media consisted of DMEM containing $10 \% \mathrm{HS}, 250 \mu \mathrm{g} / \mathrm{ml} \mathrm{G} 418,4 \mu \mathrm{M}$ dex, $2 \mathrm{~mm}$ methionine, and $2 \mathrm{~mm}$ cysteine. In experiments requiring very short labeling times, the cells were washed quickly with met/cys-deficient media just prior to addition of labeling media to remove any extracellular cold methionine still present. Following the labeling (and chase) period, the culture dish was placed on ice and $3 \mathrm{ml}$ of extraction buffer was added to each 60 $\mathrm{mm}$ dish. Following a $5 \mathrm{~min}$ incubation the cell extract was collected and centrifuged at $15,000 \times g$ for $15 \mathrm{~min}$, and the resulting supernatant collected. Cellular extracts were kept at $4^{\circ} \mathrm{C}$ throughout the solubilization process. Affinity-purified Kvl.1 antisera $(8 \mu 1 / 3 \mathrm{ml}$ cell extract) were added to the solubilized extract and incubated at RT for $2 \mathrm{hr}$ on a rocking platform. Packed Protein A Sepharose beads $(2 \mu \mathrm{l})$, preblocked with BSA as above, were added and the incubation continued for an additional $2 \mathrm{hr}$ at $\mathrm{RT}$ with rocking. Beads were then sedimented, washed, and eluted, and samples analyzed as described above. Increased incubation times at $4^{\circ} \mathrm{C}$ with either antibody or Protein $\mathrm{A}$ beads did not alter the efficiency of $\mathrm{K}^{+}$channel immune purification. No evidence for proteolysis of the channel was observed at RT relative to $4^{\circ} \mathrm{C}$.

Isolation of Kv1.1 protein expressed on the cell surface. Dex-induced cells were labeled for $16 \mathrm{hr}$ in labeling media containing $250 \mu \mathrm{Ci} / \mathrm{ml}$, washed three times with cold phosphate-buffered saline, $\mathrm{pH} 7$ (PBS) containing $0.5 \mathrm{mM} \mathrm{CaCl}$ and $0.5 \mathrm{~mm} \mathrm{MgCl}_{2}$ (PBS $+\mathrm{Ca}^{2+} / \mathrm{Mg}^{2+}$ ), and incubated with $10 \mathrm{~mm} \mathrm{NaIO}$ in $\mathrm{PBS}+\mathrm{Ca}^{2+} / \mathrm{Mg}^{2+}$ at $4^{\circ} \mathrm{C}$ for $30 \mathrm{~min}$. This last incubation was in the dark to minimize free radical production. Cells were then washed three times with cold PBS $+\mathrm{Ca}^{2+} / \mathrm{Mg}^{2+}$, followed by one wash at $4^{\circ} \mathrm{C}$ with $100 \mathrm{~mm} \mathrm{Na}$ acetate (pH 5.5) containing $1 \mathrm{mM} \mathrm{CaCl}$, and $1 \mathrm{~mm} \mathrm{MgCl} 2\left(\mathrm{NaAc}+\mathrm{Ca}^{2+} / \mathrm{Mg}^{2+}\right)$. Biotin-LC-hydrazide (Pierce, Rockford, IL) was dissolved in $100 \mathrm{~mm} \mathrm{NaAc}+\mathrm{Ca}^{2+}$ $\mathrm{Mg}^{2+}$ to a final concentration of $2 \mathrm{~mm}$ and incubated with the cells for $30 \mathrm{~min}$ at $4^{\circ} \mathrm{C}$ with gentle shaking to biotinylate cell surface carbohydrates. Cells were then washed three times with PBS, extracted with detergent solution, and incubated with Kv 1.1 antisera and subsequently with Protein A beads as detailed above. Removal of cells from the culture dish was facilitated by use of a rubber policeman. Washes were as usual, but immune-purified protein was eluted at RT with $0.2 \mathrm{ml}$ of $50 \mathrm{~mm}$ glycine $(\mathrm{pH} 2.5)$ containing $0.1 \%$ Triton $\mathrm{X}-100$, and the eluate neutralized with the addition of $30 \mu \mathrm{l}$ of $2 \mathrm{M}$ Tris, $\mathrm{pH}$ 7.5. Streptavidin Sepharose beads (Picrec; $40 \mu \mathrm{l}$ of a $50 \%$ slurry) were added to the cluate and incubated $1 \mathrm{hr}$ at RT with rocking. Streptavidin beads were sedimented and washed using the same protocol described above for Protein A beads. Elution was by boiling in SDS sample buffer. The sample was analyzed by SDS-polyacrylamide gel electrophoresis (SDS-PAGE) and fluorography.

Endoglycosidase $H$ and $\mathrm{N}$-glycanase treatment of immune isolated Kv1.1 protein. Dex-induced Kv1.1 cells ( $60 \mathrm{~mm}$ dish) were metabolically labeled overnight, immune purified, and taken through the usual washes described above. The beads were then additionally washed with $1 \mathrm{ml}$ of cold PBS. For endoglycosidase H (Endo H) treatment, beads were resuspended in $30 \mu \mathrm{l}$ of Endo $\mathrm{H}$ buffer $(0.25 \%$ SDS, $60 \mathrm{~mm} \mathrm{Na}$ acetate, $\mathrm{pH} 5.8,2 \% \beta$-mercaptoethanol; Tamkun and Fambrough, 1986) with or without $15 \mathrm{mU}(5 \mu \mathrm{l})$ of Endo H (Calbiochem, San Diego, CA) resuspended in $50 \mathrm{~mm} \mathrm{Na}$ acctate, $\mathrm{pH} 5.8$. When Endo $\mathrm{H}$ was absent, $5 \mu \mathrm{l}$ of $50 \mathrm{~mm} \mathrm{Na}$ acetate was added to the reaction. For $N$-glycanase treatment, beads were resuspended in $100 \mu \mathrm{l}$ of $N$-glycanase buffer ( 250 $\mathrm{mM} \mathrm{Na} \mathrm{HPO}_{4}$, pH 7.5, containing $10 \mathrm{~mm}$ EDTA and $10 \mathrm{~mm} \beta$-mercaptoethanol) with or without $1.5 \mathrm{U}$ of $\mathrm{N}$-glycanase (Calbiochem; 25,000 
A

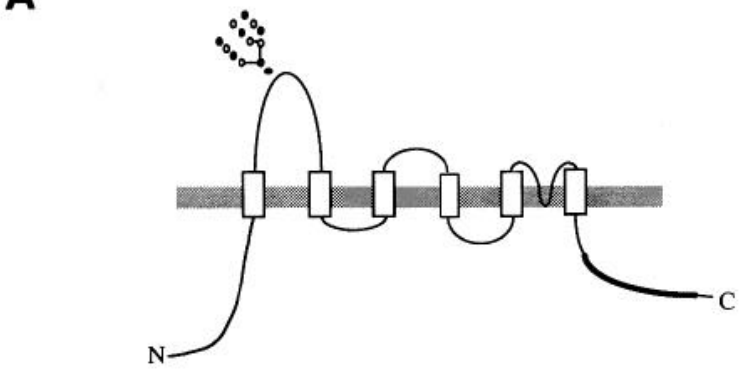

B

KV1.1 381 VTIGGKIVGSLCAIAGVLTIALPVPVIVSNFNYFYHRETEgEEQA KV1.4 534 iTVGGKIVGSLCAIAGVLTIALPVPVIVSNFNYFYHRETENEEQt S6

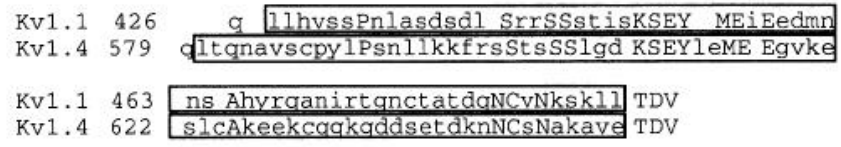

Figure 1. Generation of antibodies directed against the C-terminal amino acids of Kv1.1 and Kv1.4. A, Postulated transmembrane orientation of Kv1.1 and 1.4. A single conserved N-linked glycosylation site is indicated within the first extracellular loop and is highly conserved among members of the $\mathrm{Kv} 1$ family. The $\mathrm{C}$-terminal region against which antisera was generated is marked with a thick line. $B$, Amino acid sequence of Kv1.1 and Kv1.4 epitopes. The amino acids linked to the $\mathrm{C}$-terminal end of the fusion protein are boxed. The sixth proposed membrane spanning region is indicated as $S 6$.

$\mathrm{U} / \mathrm{mg}$ protein). In both cases, the beads were incubated overnight at $37^{\circ} \mathrm{C}$ with shaking, then washed with $1 \mathrm{ml}$ of buffer A prior to elution by boiling in SDS sample buffer. The N207Q mutant was insensitive to enzymatic treatment, confirming that proteolysis of the channel did not occur during this incubation protocol.

Western blot analysis of Kv1.1 antibody binding to L-cell membranes. Three confluent $75 \mathrm{~cm}^{2}$ flasks (approximately $6 \times 10^{7}$ cells/flask) of Kv1.1- and sham-transfected cells were induced with $4 \mu \mathrm{M}$ dex $24 \mathrm{hr}$ prior to membrane preparation. Cells were washed several times in icecold PBS to remove media and harvested into $7.5 \mathrm{ml}$ of ice-cold 0.32 M sucrose, $5 \mathrm{~mm} \mathrm{Na}{ }_{2} \mathrm{HPO}_{4}$, $\mathrm{pH} 7.4$, containing protease inhibitors. Cells were pooled and homogenized with 18 strokes of a Dounce homogenizer. Lysed cells were sedimented at $1000 \times g, 4^{\circ} \mathrm{C}$, for $10 \mathrm{~min}$ and the resulting supernate was then sedimented at $17,000 \times g, 4^{\circ} \mathrm{C}, 1 \mathrm{hr}$. The final pellet was resuspended in $\sim 150 \mu \mathrm{l}$ PBS and stored at $-80^{\circ} \mathrm{C}$. Fifteen microliters of membranes were used for Western blot analysis.

Following electrophoresis, the gel was equilibrated for $30 \mathrm{~min}$ in transfer buffer ( $12.5 \mathrm{~mm}$ Tris, $96 \mathrm{~mm}$ glycine, and $20 \% \mathrm{v} / \mathrm{v}$ methanol, final $\mathrm{pH} 8.5$ ) containing $0.1 \%$ SDS. Transfer to nitrocellulose (Schleicher \& Schuell, Keene, $\mathrm{NH}$ ) was for $2 \mathrm{hr}, 125 \mathrm{~V}$ in a Trans-Blot apparatus (Bio-Rad Laboratories), maintaining the transfer buffer at $4^{\circ} \mathrm{C}$. The nitrocellulose was incubated overnight at $4^{\circ} \mathrm{C}$ in solution 1 (S1) $[50 \mathrm{~mm}$ Tris, pH 7.5, $150 \mathrm{~mm} \mathrm{NaCl}, 10 \%$ goat serum (GIBCO)]. All subsequent steps were performed at RT. The blot was incubated in solution 2 (S2) ( $50 \mathrm{~mm}$ Tris, $\mathrm{pH} 7.5,150 \mathrm{~mm} \mathrm{NaCl}, 5 \%$ goat serum, $0.05 \%$ Tween 20 ) containing 1:400 dilution of affinity-purified Kv1.1 antisera for $2.5 \mathrm{hr}$, washed twice for $15 \mathrm{~min}$ in solution 3 (S3; $50 \mathrm{~mm}$ Tris, pH 7.5, $0.5 \mathrm{M}$ $\mathrm{NaCl}, 5 \%$ goat serum, $0.05 \%$ Tween 20 ), and incubated for $1 \mathrm{hr}$ in S2 containing a 1:7500 dilution of horseradish peroxidase-conjugated goat anti-rabbit IgG (Sigma). The blot was then washed sequentially $15 \mathrm{~min}$ in $\mathrm{S} 1,15 \mathrm{~min}$ in $\mathrm{S} 2,15 \mathrm{~min}$ in $\mathrm{S} 3$, and detection achieved with the enhanced chemiluminescence kit (ECL) from Amersham Corp. (Arlington Heights, IL). Generally, an adequate exposure of film was obtained in $7-30$ sec.

Other methods. SDS-polyacrylamide gel electrophoresis using $10 \%$ gels on the Protean II minigel apparatus (Bio-Rad Laboratories, Richmond, CA) and subsequent fluorography were performed as previously described in detail (Fambrough and Bayne, 1983). Although data pre-
A

B
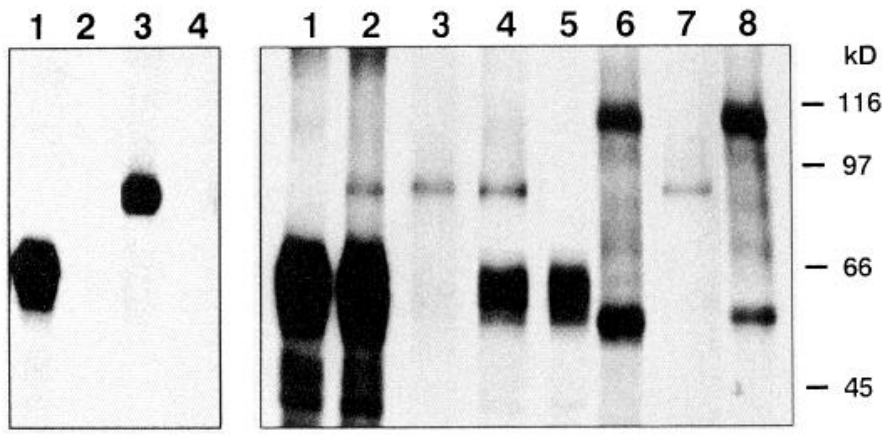

Figure 2. Assembly of Kv1.1 and Kv1.4 channel subunits. A, Isoform specificity of Kv1.1 and Kv1.4 antisera. Kv1.1 (lanes 1, 4) and Kv1.4 (lanes 2, 3) protein was translated in vitro in the presence of canine microsomal membranes using ${ }^{35} \mathrm{~S}$-methionine. The reaction mixture was detergent solubilized, incubated with either Kv1.1 (lanes 1, 2) or Kv1.4 (lanes 3, 4) antisera, and adsorbed to Protein A Sepharose as detailed in Materials and Methods. Purified channel protein was eluted and analyzed by SDS-PAGE and fluorography. Exposure was $2.5 \mathrm{~d}$. $B$, Assembly of Kv1.1 and Kv1.4 channel subunits following in vitro translation. Kvl.1 and Kv1.4 proteins were either translated in separate reactions and mixed just prior to a $1 \mathrm{hr}$ solubilization period (lanes 1 3 ) or translated in the same reaction (lanes 2, 4) and subsequently solubilized for $1 \mathrm{hr}$ and immune purified with either Kv1.1 (lanes 1, 2) or Kv1.4 (lanes 3,4) antibodies. Kv1.1 and Kv2.1 proteins were translated in the same reaction (lanes 5,6 ) and subsequently immune purified with either Kv1.1 (lane 5) or Kv2.1 (lane 6) antibodies. Kv1.4 and Kv2.1 proteins were translated in the same reaction (lanes 7,8 ) and subsequently immune purified with either Kv1.4 (lane 7) or Kv2.1 (lane 8 ) antibodies. Exposure was 3-9 d to account for variation in immune purification efficiency. The mobilities of molecular weight markers are shown to the right.

sented may represent a single experiment, all studies were performed in at least three separate experiments. Additional details are presented in the figures.

\section{Results}

In vitro assembly of Kv1.1 and Kv1.4 channel subunits. Before questions relating to the biosynthesis and processing of $\mathrm{K}^{+}$channels could be addressed, it was first necessary to generate antibodies that would allow immune purification of native protein from detergent extracts. Polyclonal antisera were raised against both the Kv1.1 and Kv1.4 C-terminal amino acids as described in Materials and Methods and shown in Figure 1. Since the amino acid sequence used as the immunogen varied greatly between isoforms, the antisera were predicted to be isoform specific. Immune purification studies with channel protein synthesized in a microsome-containing in vitro translation extract confirmed this prediction. The Kvl.1 antibodies immune purified the Kv1.1 channel ( $57-59 \mathrm{kDa})$ but not the Kv1.4 channel (73-75 kDa) from detergent extracts of the translation reaction as shown in lanes 1 and 2 of Figure $2 A$. Isoform specificity was also shown for the $\mathrm{Kvl} .4$ antibodies as indicated in lanes 3 and 4.

Since both preparations of antibodies did not cross-react with either the Kv1.1 or 1.4 channels, the ability of one antibody to immune purify both channels following cotranslation was assessed. Copurification here is taken as an operational definition of subunit assembly and was readily detectable by SDS gel elec- 


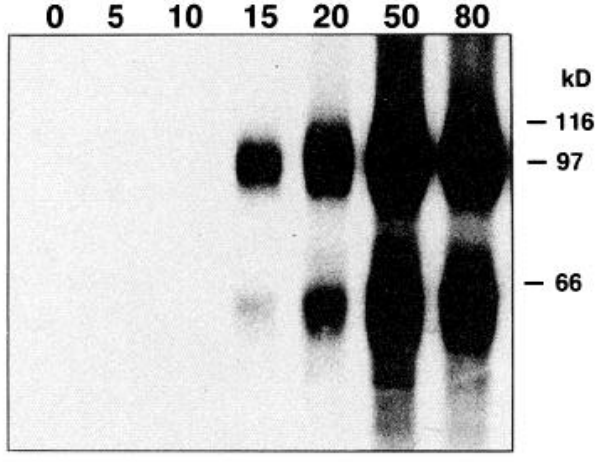

Figure 3. Time course of Kv1.1 and Kv1.4 interaction following in vitro translation. $\mathrm{Kv} 1.1$ and $\mathrm{Kv} 1.4$ proteins were translated in a single in vitro reaction, and aliquots taken at the indicated times and subject to solubilization and immune purification with $\mathrm{Kv1} .4$ antisera as described in Materials and Methods.

trophoresis (Fig. 2). Such copurification is only an indication of association, not fully functional tetramerization. As shown in Figure $2 B$, cotranslation of Kv 1.1 and 1.4 resulted in the affinity purification of both channels with either the Kv1.1 antibody (lane 2) or the Kv1.4 antibody (lane 4). The ratios of the two isoforms varied greatly depending on the antibody used for the immune purification (compare lanes 2,4 ). To confirm that association did not result from the simple adsorption of one subunit onto the other during the detergent solubilization and purification protocol, $\mathrm{Kvl} .1$ and $\mathrm{Kv1} .4$ proteins were synthesized separately, mixed, detergent solubilized, and then carried through the immune purification protocol. As shown in lanes 1 and 3 of Figure $2 B$, no copurification was observed here, as is predicted if the assembly of the two channels is dependent on cotranslation. The Kv2.1 channel does not form functional heterotetramers with the Kv1.1 channel or other Shaker-like K+ channels (Covarrubias et al., 1991). This lack of heteromeric function could be due to lack of subunit association or simply the fact that the assembled heterotetramer is nonfunctional. Therefore, assembly was assessed between Kv1.1 and Kv2.1. As shown in lanes 5 and 6, no copurification resulted with either the Kv1.1 or Kv2.1 antibodies, suggesting that these two isoforms do not physically associate with each other. In addition, lack of copurification of the Kv1.4 and Kv2.1 channels with each other (lanes 7 and 8) also supports the idea that assembly does not occur across $\mathrm{K}^{+}$channel subfamilies. The lower species $(\sim 54$ $\mathrm{kDa}$ ) in lanes 6 and 8 may represent either an early termination in the synthesis of the Kv2.1 protein or a proteolytic fragment.

A time course of association study was performed as shown in Figure 3 to determine whether a delay exists between polypeptide synthesis and isoform association. Copurification of both isoforms was detected at the earliest time point $(15 \mathrm{~min})$ at which protein synthesis was detected. These data suggest that subunit association is rapid, perhaps even cotranslational. Since the antibodies are directed against the C-terminal amino acids, only fully synthesized protein was detected. It is possible that assembly begins early in translation, perhaps via the interaction of $\mathrm{N}$-terminal sequence as previously suggested by $\mathrm{Li}$ et al. (1992).

Immune purification of total and cell surface Kv1.1 channel protein. While the data obtained with the in vitro translation system are useful in addressing questions relating to subunit association, they reveal little with respect to the processing of
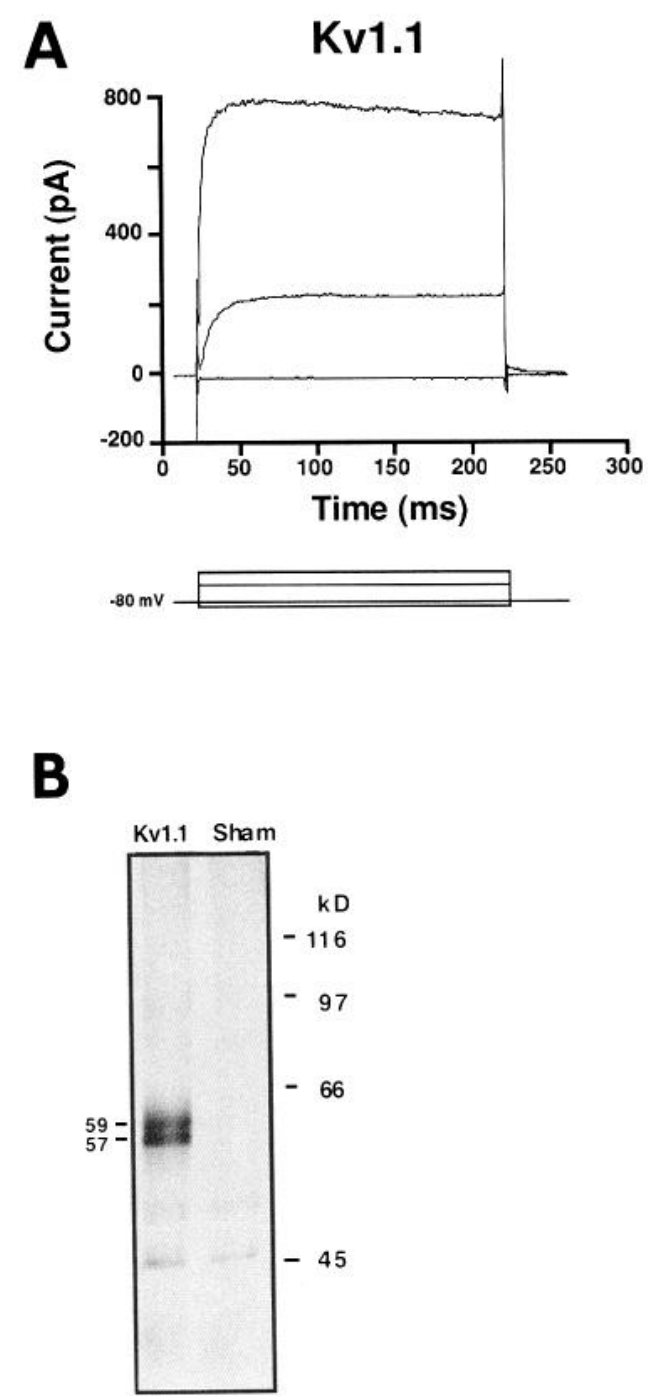

Figure 4. Expression of the Kv1.1 channel in mouse L-cells. A, Outward currents recorded in response to depolarizing stimuli. Standard whole-cell voltage-clamp techniques were used to elicit outward currents by changing the membrane potential to $-90,-25$, and $0 \mathrm{mV}$ from a holding potential of $-80 \mathrm{mV}$. Voltage-clamp conditions and solutions are described in Materials and Methods. $B$, Immune purification of Kv1.1 protein. Kv1.1-transfected (lane 1) or sham-transfected (lane 2) cells were metabolically labeled with $275 \mu \mathrm{Ci} / \mathrm{ml}^{35} \mathrm{~S}$-met $/{ }^{35} \mathrm{~S}$-cys for 18 $\mathrm{hr}$, affinity purified with Kvl.1 antisera from whole-cell detergent extracts, and analyzed by SDS-PAGE and fluorography. Exposure was 4.5 d. The molecular weight of each species of the Kvl.1 doublet is indicated to the left.

the channel protein in a mammalian cell. Therefore, the Kv1.1 channel was expressed in a stable mouse L-cell line as described in Materials and Methods. Channel function was measured by whole-cell voltage-clamp and immune purification studies were performed to examine the channel protein directly. As shown in Figure $4 A$, expression of the Kv1.1 channel generated a delayed rectifier-like current activating at potentials positive to $-40 \mathrm{mV}$. These currents are similar to those recorded from Xenopus oocytes (Christie et al., 1989) and sol-8 cells (Koren et al., 1990) expressing this channel. Sham-transfected cells, containing the expression vector without the channel cDNA and processed in an identical fashion as the Kv1.1-expressing cells, showed no voltage or time dependent currents (data not shown). 
Immune purifications with the Kv1.1 antibody from detergent extracts of Kv1.1-expressing cells metabolically labeled for 18 $\mathrm{hr}$ resulted in the isolation of two distinct species on an SDS gel with molecular weight of 59 and $57 \mathrm{kDa}$ (Fig. $4 B$, lane 1). These two proteins were not observed in immune purifications from the sham-transfected cells (lane 2). Other minor proteins that immune purified from the Kv1.1-expressing cells were also seen in the sham-transfected cells, indicating nonspecific adsorption of cellular proteins to the antibody-Protein A bead complex. The tightly associated doublet at 57 and $59 \mathrm{kDa}$ was reproducible but at times difficult to resolve. Alteration to the gel system, reducing conditions, acrylamide percentage, and electrophoretic conditions did not alter the doublet.

One difficulty in comparing the voltage-clamp data of Figure $4 A$ with the immune purifications of Figure $4 B$ is that voltage clamp examines only functional cell surface protein, whereas the immune purification examines total channel protein, both intracellular and cell surface. Since the immune purifications were not quantitative, it was possible that the pool of functional surface channels was a small percentage of total channel protein and not represented by the $57 / 59 \mathrm{kDa}$ doublet. To address this issue, the cell surface channel was affinity purified using the biotinylation method described in Materials and Methods. As shown in Figure 5, lane 1, a broad band with the electrophoretic mobility of the doublet was detected following affinity purification from the cell surface, as was a diffuse band with a molecular weight of $100 \mathrm{kDa}$. The biotinylation procedure never allowed resolution of the $57 / 59 \mathrm{kDa}$ doublet and the $100 \mathrm{kDa}$ band was not observed in all surface channel isolations. Lane 2 shows the result of the exact same protocol used in lane 1 except that the biotin hydrazide treatment of intact cells was not undertaken. Lanes 3 and 4 were generated as in lanes 1 and 2 except that sham-transfected cells were used as the starting material. The lack of 57-59 $\mathrm{kDa}$ band purification from the $\mathrm{Kv1}$.1-expressing cells not treated with biotin or from the biotintreated, sham-expressing cells indicates that the 57-59 kDa band is a true representation of $\mathrm{Kv} 1.1$ cell surface protein, most likely representing the doublet that cannot be resolved due the modifications involved in biotinylation. In addition, the cell surface Kv1.1 protein must be glycosylated since it was the surface carbohydrate that was biotinylated. Several experiments suggest that the $100 \mathrm{kDa}$ protein of lane 1 represents an artifact resulting from the cross-linking of $\mathrm{Kv} 1.1$ subunits to one another or to another protein. Incubation with $\mathrm{NaIO}_{4}$ makes the cells more difficult to solubilize, as expected if membrane protein crosslinking occurs, and channel protein aggregates are seen on top of lane 1. When the cell surface is activated with $\mathrm{NaIO}_{4}$ but not biotinylated and total Kv1.1 protein immune purified, the 100 $\mathrm{kDa}$ aggregate is often observed (data not shown). Evidently, $\mathrm{NaIO}_{4}$ oxidized Kv1.1 carbohydrate moieties to form aldehydes (O'Shannessy and Quarles, 1985), and these aldehydes covalently cross-linked to neighboring proteins. Finally, as shown in lane 5, when total membranes from Kv1.1-expressing cells were electrophoretically separated, transferred to nitrocellulose, and incubated with Kvl.1 antibody, only the $57 / 59 \mathrm{kDa}$ doublet was observed. Doublet resolution was readily detected on the original film but this image was lost upon reproduction. The detection of both doublet bands by the Kv1.1 antibody in lane 5 confirmed that both components represented Kv1.1 protein as opposed to one protein being a tightly associated accessory subunit or protein. Lane 6 shows an identical immunoblot performed with sham-transfected cells.

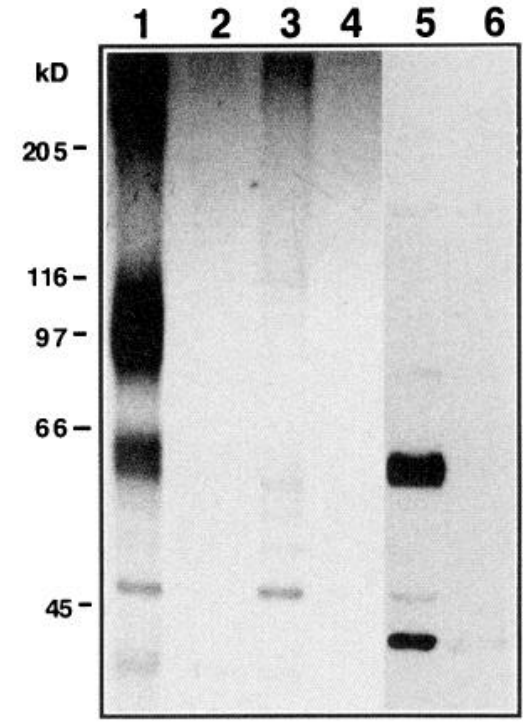

Figure 5. Analysis of cell surface Kv1.1 protein. Following $4 \mathrm{hr}$ of dex treatment and a metabolic labeling period of $16 \mathrm{hr}$ in media containing $400 \mu \mathrm{Ci} / \mathrm{ml}^{35} \mathrm{~S}$-met $/{ }^{35} \mathrm{~S}$-cys, cell surface carbohydrate moieties were labeled with biotin and detergent solubilized. The detergent-solubilized extracts were then incubated with Kv1.1 antisera and subsequently with Protein A Sepharose. Purified proteins were eluted and incubated for 1 $\mathrm{hr}$ with immobilized streptavidin. Proteins that adsorbed to the streptavidin beads were eluted by boiling in SDS sample buffer and analyzed by SDS-PAGE. Lane 1, immune purification from Kv1.1 cell surface; lane 2, immune purification conducted as in lane 1, except that activated carbohydrate moieties were not incubated with biotin hydrazide; lane 3 , immune purification from cell surface of sham-transfected cells; lane 4 , immune purification conducted as in lane 3, except that activated carbohydrate moieties were not incubated with biotin hydrazide. Exposure was for $6 \mathrm{~d}$. Lanes 5 and 6 show Western analyses of cell membranes. Membranes from Kv1.1 (lane 5) and sham-transfected (lane 6) cells were run on SDS-PAGE and transferred to nitrocellulose, and Kv1.1 antibody binding was detected by horseradish-peroxidase enhanced chemiluminescence.

Posttranslational processing events involved in Kv1.1 biosynthesis. The metabolic labeling and Western blot data presented thus far represent Kvl.1 channel protein that is near a steadystate level of expression, and thus relatively mature. Both the labeling and preparation of membranes for Western blot analysis were performed 16-24 $\mathrm{hr}$ after the induction of channel synthesis. In order to examine early events in Kv1.1 biosynthesis, the pulse-chase experiment illustrated in Figure 6 was performed. Cells expressing Kv1.1 were metabolically labeled for $7 \mathrm{~min}$ with media containing $1 \mathrm{mCi} / \mathrm{ml}^{35} \mathrm{~S}$-met $/{ }^{35} \mathrm{~S}$-cys and then incubated in chase media containing $2 \mathrm{~mm}$ met and $2 \mathrm{~mm}$ cys for the indicated periods of time prior to immune purification. At the start of the chase period, only a single $57 \mathrm{kDa}$ species was observed. However, at $10 \mathrm{~min}$ into the chase, the $59 \mathrm{kDa}$ species was evident and the presence of this protein increased at the expense of the $57 \mathrm{kDa}$ protein, consistent with a precursor-product relationship between the two. By $4 \mathrm{hr}$ most of the $57 \mathrm{kDa}$ protein had disappeared. However, total radioactivity remained relatively constant between 0 and $4 \mathrm{hr}$, as determined by laser densitometry, confirming that there was not a rapid component to Kv1.1 degradation during this period. At increasing chase times $(8 \mathrm{hr})$ a $57 \mathrm{kDa}$ protein reappeared, indicating a precursor-product relationship whereby a fraction of the $59 \mathrm{kDa}$ protein was converted to a $57 \mathrm{kDa}$ form (data not shown). This later conversion explains why mature protein was 


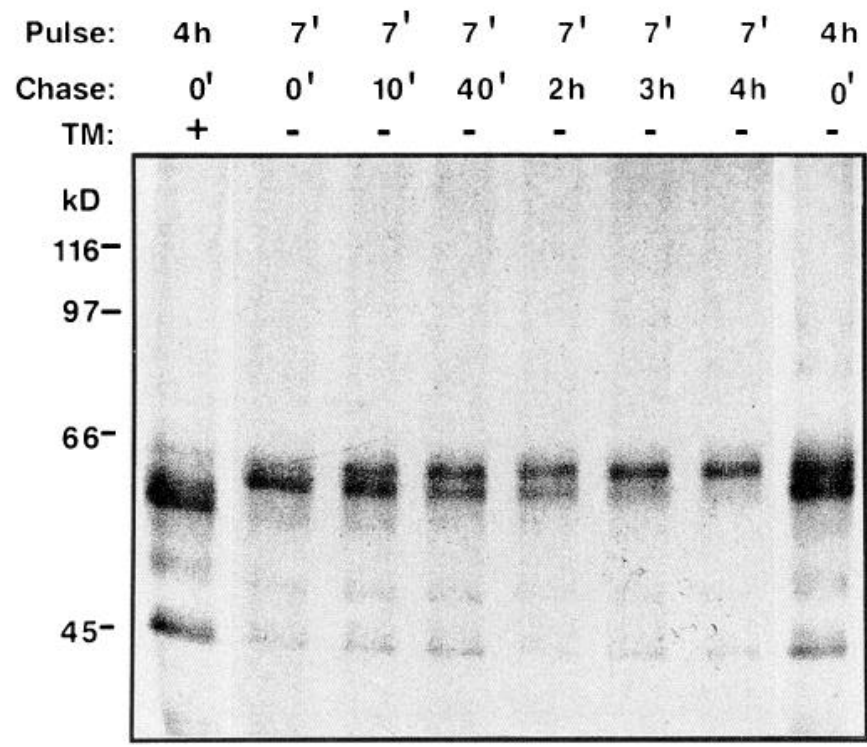

Figure 6. Pulse-chase analysis of Kvl.1 synthesis. Cells expressing $\mathrm{Kv} 1.1$ were incubated with dex for $12 \mathrm{hr}$, metabolically labeled for either $7 \mathrm{~min}$ with media containing $1 \mathrm{mCi} / \mathrm{ml}{ }^{35} \mathrm{~S}$-met $/{ }^{35} \mathrm{~S}$-cys or for 4 hr with media containing $575 \mu \mathrm{Ci} / \mathrm{ml}^{35} \mathrm{~S}$-met/35 $\mathrm{S}$-cys in the presence (far left lane) or absence (far right lane) of $30 \mu \mathrm{g} / \mathrm{ml}$ tunicamycin. Labeled cells were then incubated in chase media containing $2 \mathrm{~mm}$ met and $2 \mathrm{~mm}$ cys for the indicated periods of time prior to detergent solubilization. Immune purification of $\mathrm{Kv} 1.1$ protein and analysis by SDSPAGE was as described in Materials and Methods. Exposure was $8 \mathrm{~d}$.

represented by 57 and $59 \mathrm{kDa}$ species of equal intensity while early biosynthetic events indicated that the $57 \mathrm{kDa}$ species was a precursor to the $59 \mathrm{kDa}$ protein. Determination of whether the $57 \mathrm{kDa}$ species detected early in synthesis represents the same posttranslational modifications as the $57 \mathrm{kDa}$ protein seen under steady-state conditions will require further investigation.

Role of $\mathrm{N}$-linked glycosylation at Asn 207 of Kv1.1. Both nascent and mature Kv1.1 protein were treated with endoglycosidase $\mathrm{H}$ (Endo $\mathrm{H}$ ) and $\mathrm{N}$-glycanase in order to address the type of carbohydrate (high mannose or complex) present. The 57 $\mathrm{kDa}$ protein synthesized during a short labeling $(10 \mathrm{~min})$ was

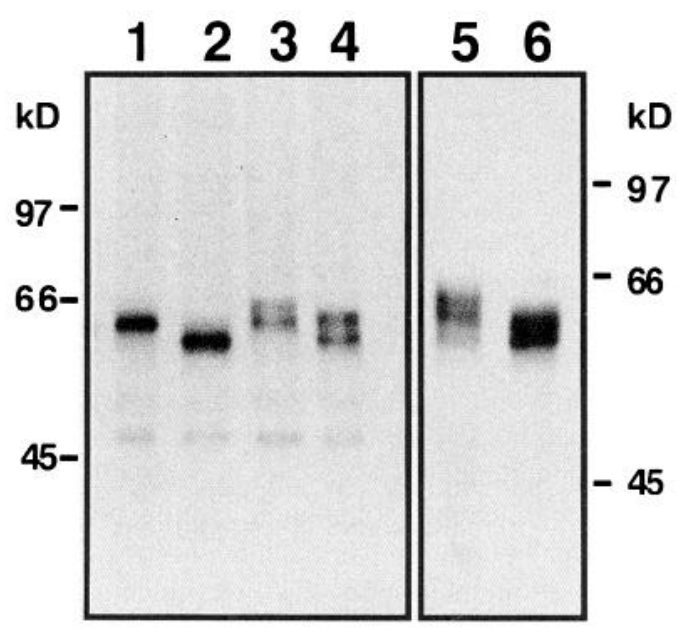

Figure 7. Glycosidase treatment of $\mathrm{Kv1} 1.1$ protein isolated from transfected L-cells. Cells were labeled for either 10 min (lanes 1, 2) or $18 \mathrm{hr}$ (lanes 3-6) and Kv1.1 protein was purified and treated with $\mathrm{N}$-glycanase (lanes 2, 4), $N$-glycanase buffer alone (lanes 1, 3), Endo H (lane 6), or Endo $\mathrm{H}$ buffer alone (lane 5 ) as described under Materials and Methods.

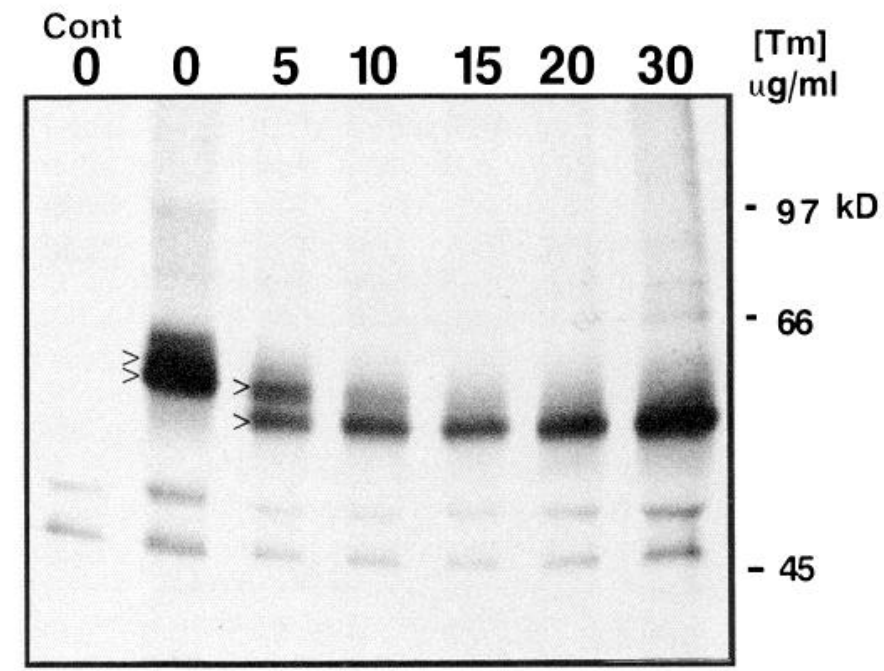

Figure 8. Effect of tunicamycin on Kv1.1 electrophoretic mobility. Kv1.1-expressing cells were preincubated in $4 \mu \mathrm{M}$ dex and the indicated concentrations of tunicamycin for $3 \mathrm{hr}$ prior to a $4 \mathrm{hr}$ metabolic labeling with $575 \mu \mathrm{Ci} / \mathrm{ml}^{35} \mathrm{~S}-\mathrm{met} /{ }^{35} \mathrm{~S}$-cys in the continued presence of tunicamycin. The cells were detergent solubilized and Kv1.1 protein was immune purified as described in Materials and Methods. Exposure was for $1 \mathrm{~d}$. The Cont lane (control) represents an immune purification with Kv1.1 antisera from sham-transfected cells metabolically labeled for 4 $\mathrm{hr}$ in the absence of $30 \mu \mathrm{g} / \mathrm{ml}$ tunicamycin. Arrowheads indicate doublet bands.

$N$-glycanase sensitive, being completely shifted to a $55 \mathrm{kDa}$ species as shown in Figure 7, lanes 1 and 2. Such an effect of glycosidase treatment is predicted if cotranslational N-linked glycosylation occurs (Abeijon and Hirschberg, 1992). When Kv1.1 protein was metabolically labeled for a longer period (18 hr) and then treated with $N$-glycanase, a doublet was still observed but with mobilities of 55 and $\sim 58 \mathrm{kDa}$ (lanes 3,4 ). Posttranslational modifications other than N-linked glycosylation must be involved; otherwise, $N$-glycanase treatment would have reduced both components of the doublet to the $55 \mathrm{kDa}$ position, which most likely represents the carbohydrate-free core peptide. Endo $\mathrm{H}$ treatment (lanes 5,6) yielded results similar to those with $N$-glycanase, suggesting little, if any, of the high mannose carbohydrate was converted to the complex form in the Golgi.

Since the Kv1.1 protein was susceptible to $N$-glycanase and Endo $\mathrm{H}$, tunicamycin was used to block $N$-linked glycosylation at the level of dolichol transferase (Keller et al., 1979). Figure 8 shows the effect of increasing tunicamycin concentrations on the electrophoretic pattern of immune-purified Kv1.1. At 1-5 $\mu \mathrm{g} / \mathrm{ml}$ tunicamycin, the $59 \mathrm{kDa}$ species was completely absent while the putative $55 \mathrm{kDa}$ core peptide was now present. The $57 \mathrm{kDa}$ species did not fully disappear until tunicamycin concentrations as great as $30 \mu \mathrm{g} / \mathrm{ml}$ were used. This differential sensitivity of the 57 and $59 \mathrm{kDa}$ species to tunicamycin again suggests that these two species represent distinct posttranslational modifications. Since tunicamycin is known to affect modifications other than $\mathrm{N}$-linked glycosylation (Schmidt and Catterall, 1987), it is possible that the effect of tunicamycin concentrations above $5 \mu \mathrm{g} / \mathrm{ml}$ was due to alteration of another type posttranslational modification such as acylation. However, preliminary experiments to detect acylation and phosphorylation were unsuccessful (data not shown).

It was next determined whether tunicamycin affected the 
A

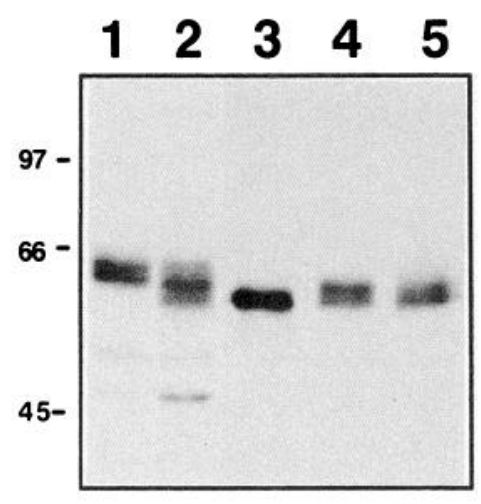

B

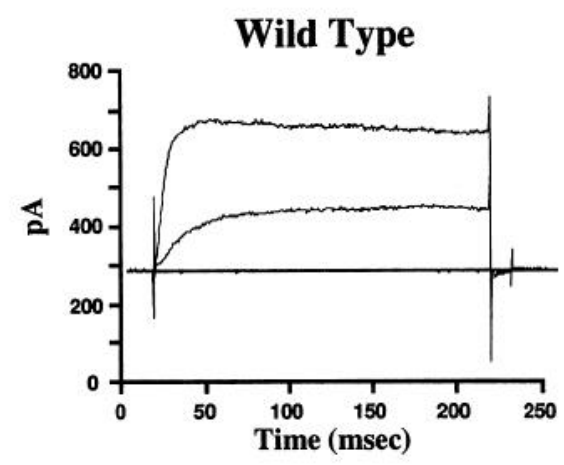

\section{Glycosylation Mutant}

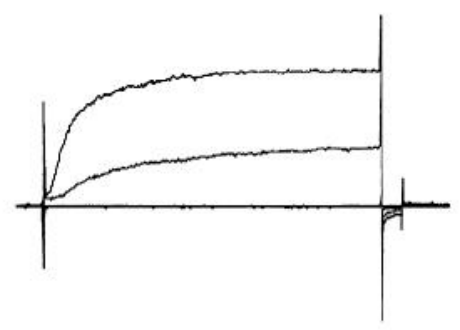

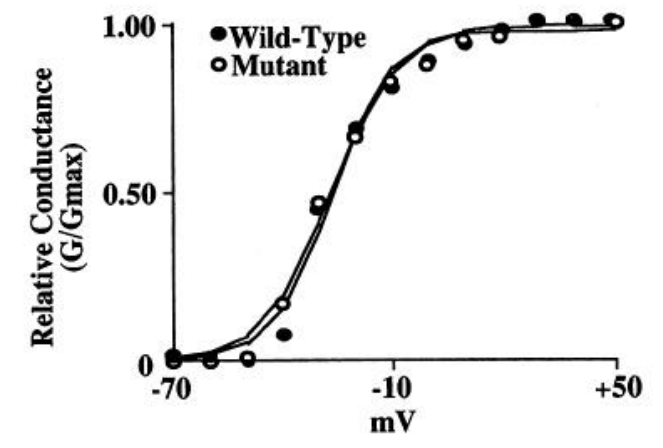

transport of nascent Kv1.1 to the cell surface. If the observed posttranslational modifications were required for either subunit assembly, intracellular transport, or ion channel activity, then functional channels should not be seen in the presence of $30 \mu \mathrm{g} /$ $\mathrm{ml}$ of tunicamycin. As stated above, tunicamycin has other effects and can severely depress overall protein synthesis, demanding that this experiment be interpreted with caution. How-
Figure 9. Removal of N-linked glycosylation does not alter Kv1.1 biosynthesis or function. $A$, Immune purification of Kv1.1 protein. Cells transfected with either the wild-type Kv1.1 or N207Q Kv1.1 constructs were metabolically labeled with $250 \mu \mathrm{Ci} / \mathrm{ml}$ ${ }^{35} \mathrm{~S}$-met $/{ }^{35} \mathrm{~S}$-cys and detergent solubilized, and the whole-cell extract was incubated with Kv1.1 antisera, followed by adsorption to Protein A Sepharose. The immune-purified protein was eluted in SDS-sample buffer by boiling and analyzed on SDS-PAGE. Exposure was $18 \mathrm{hr}$. Lane 1 shows the native Kv1.1 protein while lane 2 shows the N207Q mutant after $18 \mathrm{hr}$ of labeling. Lanes 3-5 show the electrophoretic patterns of the N207Q mutant following $7 \mathrm{~min}$ of labeling with $1 \mathrm{mCi} / \mathrm{ml}^{35} \mathrm{~S}$-met $/{ }^{35} \mathrm{~S}$ cys and chase periods of 0 min (lane 3 ), $30 \mathrm{~min}$ (lane 4 ) and $3.5 \mathrm{hr}$ (lane 5). B, Whole-cell voltage-clamp analysis. Currents activated by 250 -msec-duration voltage steps to $-90,-30$ and 0 $\mathrm{mV}$ from a holding potential of -80 $\mathrm{mV}$ in L-cells expressing wild-type Kv1.1 and N207Q mutant channels are as indicated. A brief step to $-100 \mathrm{mV}$ is given after each $250 \mathrm{msec}$ voltage step to show tail current. $C$, Voltageactivation curves. Note the similarity of the voltage dependence of channel activation in the wild-type Kv1.1- and N207Q Kv1.1-expressing cells. Activation curves were fitted by a single Boltzmann function using Nonlin II (Stephen Ikeda, Medical College of Georgia) as described in Materials and Methods. Estimates of membrane potential at which conductance was halfmaximal were $30.9 \pm 3 \mathrm{mV}$ for the $\mathrm{Kvl} 1.1$ cells and $30.7 \pm 4.4 \mathrm{mV}$ for the N207Q Kv1.1 cells $(N=7)$. The slope factors were $7.94 \pm 0.69$ and $9.94 \pm$ 1.22 for wild-type and N207Q Kv1.1 cells, respectively. Unpaired $t$ value for the slope factors $=1.43, p>0.05$, df $=12$. ever, as shown in the dose-response curve of Figure 8, even 30 $\mu \mathrm{g} / \mathrm{ml}$ tunicamycin had little effect on overall protein synthesis. Voltage-clamp analysis of L-cells dex-induced in the presence of $30 \mu \mathrm{g} / \mathrm{ml}$ tunicamycin failed to detect functional Kv1.1 channels at either 12 or $26 \mathrm{hr}$ after channel induction (data not shown). However, even after $26 \mathrm{hr}$ in the presence of tunicamycin, the cells showed normal passive electrical properties and 
normal resting potentials. These data suggest three possibilities: (1) N-linked glycosylation is required for the appearance of functional cell surface channel, (2) another tunicamycin-sensitive posttranslational event may be important, or (3) tunicamycin is nonspecifically inhibiting $\mathrm{Kvl} .1$ biosynthesis. Attempts to isolate the surface Kv1.1 channel synthesized in the presence of tunicamycin via direct biotinylation of channel protein were not undertaken since biotinylation of extracellular Kv1.1 protein was extremely inefficient (data not shown).

To assess directly the role of N-linked glycosylation at the single putative extracellular site of Kv1.1, Asn 207 was mutated to a glutamine residue and expressed in L-cells. The immune purification/pulse-chase analysis presented in Figure $9 A$ shows that this mutation resulted in a mature protein consisting of a doublet of $55 \mathrm{kDa}$ and $57 \mathrm{kDa}$ (lane 2). Pulse-chase experiments with a short labeling time indicated that the $55 \mathrm{kDa}$ protein was synthesized first (lane 3) and later gave rise to the $57 \mathrm{kDa}$ species (lanes 4, 5). Lack of carbohydrate at this site had no effect on protein turnover (data not shown), and as shown in Figure 9, $B$ and $C$, wild-type currents were detected on the cell surface in terms of voltage dependence and density. The results presented here demonstrate that glycosylation at Asn 207 plays no apparent role in subunit assembly, turnover, transport to the cell surface, or function.

\section{Discussion}

Our goals here were to examine basic issues concerning the biosynthesis and functional expression of the Kv1.1 $\mathrm{K}^{+}$channel. The questions addressed relate to the time course of subunit assembly, the posttranslational modifications to which the channel is subject, and the role of N-linked glycosylation at Asn 207. In the rat, Kv1.1 channel mRNA is primarily expressed in brain, with lower levels of expression in atrium, aorta, and skeletal muscle (Roberds and Tamkun, 1991). While the L-cell system may not process the Kv1.1 channel in a manner identical to that occurring in these tissues, the present study lays the foundation for the comparison of channel synthesis and processing between a heterologous system and native tissue.

Heteromeric subunit assembly occurs rapidly following channel synthesis. Association between in vitro translated Kvl.1 and Kv1.4 subunits is observed as soon as protein synthesis is detected, suggesting that in vivo assembly occurs in the endoplasmic reticulum. The fact that unassembled subunits are not detected even with short synthesis times suggests that subunit association occurs either during translation or immediately following completion of the channel peptide. The identification by Li et al. (1992) of amino acid sequence in the N-terminus of the Shaker $\mathrm{K}^{+}$channel involved in subunit interaction suggests specific $\mathrm{N}$-terminal regions of the channel subunits may interact even before the first membrane-spanning segment is synthesized. The data presented here do not determine whether the channels are functional immediately after subunit association, and in fact, it is possible functional tetramers do not form until later in channel biosynthesis. However, the finding by Rosenberg and East (1992) that Shaker channels synthesized in vitro are functional when reconstituted in a lipid bilayer indicates functional channels are formed in the in vitro synthesis system.

Glycosylation at Asn 207 is not required for subunit assembly, intracellular transport, or function. Mutation of the Asn 207 glycosylation site had no effect on the appearance of functional cell surface channels. Therefore, this modification is not essen- tial for subunit asscmbly, intraccllular transport, function, or protein stability. This site is well conserved among all members of the Kvl.1 family across species even though flanking sequence in this region varies greatly among isoforms. Why this site is well conserved among all members of the $\mathrm{Kvl} \mathrm{K}+$ channel family but absent from the Kv2 and $\mathrm{Kv} 4$ families remains in question. N-linked glycosylation is essential for the proper expression of the viral coat protein hemagglutinin ( $\mathrm{Ng}$ et al., 1990) and the voltage-gated sodium channel present in rat embryonic cortical neurons (Zona et al., 1990) and neuroblastoma cells (Waechter et al., 1983). It is also required for the appropriate spatial distribution of sodium channels to the axon of the squid neuron (Gilly et al., 1990). However, N-linked glycosylation plays no known function in the subunit assembly and intracellular transport of the $\mathrm{Na}^{+} / \mathrm{K}^{+}$-ATPase (Tamkun and Fambrough, 1986). Likewise, all the N-linked glycosylation sites can be deleted from the muscarinic acetylcholine ( $\mathrm{mACh}$ ) receptor, and it still appears on the surface with wild-type function (Van Koppen and Nathanson, 1990). However, in the case of the $\mathrm{mACh}$ receptor, tunicamycin blocks movement of functional receptors to the surface in a fashion similar to that reported here for the Kvl.1 channel. Perhaps the tunicamycin-induced block of Kv1.1 processing (other than glycosylation at N207) is essential for the appearance of functional surface channels. Alternatively, tunicamycin could be indirectly interfering with channel protein trafficking.

Biosynthesis and posttranslational modification of Kv1.1 in the L-cell system is complex. $\mathrm{N}$-linked glycosylation and subunit assembly occur during or immediately after polypeptide synthesis. Since the antibodies used in this study bind the C-terminal amino acids, and therefore recognize only fully synthesized protein, subunit assembly may begin before translation is completed. Within minutes of synthesis, the high-mannose 57 $\mathrm{kDa}$ intermediate begins a complete conversion to the $59 \mathrm{kDa}$ form. An analogous conversion $(55 \rightarrow 57 \mathrm{kDa})$ appears to occur with the N207Q mutant, suggesting this modification is independent of the N207 glycosylation (Fig. 9A, lanes 3-5). Whether this event involves lipid addition or phosphorylation will require further study. During the next several hours of channel biosynthcsis, a fraction, avcraging $50 \%$, of the $59 \mathrm{kDa}$ protein is converted to a $57 \mathrm{kDa}$ species (data not shown). This conversion is why nascent channel gives the same electrophoretic pattern as mature protein. The time course of this event was variable and less exact than the precursor-product relationship shown in Figure 6. This variability will require further study and may suggest that conversion between the mature 57 and 59 $\mathrm{kDa}$ species is not unidirectional. This late processing event may involve simple reversal of the earlier step, for example, dephosphorylation, an additional modification, or both. Whatever the nature of this modification, the $57 / 59 \mathrm{kDa}$ doublet now represents the mature form that is found on the cell surface.

The conversion of some of the $59 \mathrm{kDa}$ protein to the mature $57 \mathrm{kDa}$ species is puzzling in light of the tetrameric nature of voltage-gated $\mathrm{K}^{+}$channels. Our best estimate is that approximately one-half of the cell surface channel subunits are of each electrophoretic mobility. However, at present we cannot distinguish between two separate populations of channels on the surface or heteromeric channels composed of perhaps two $59 \mathrm{kDa}$ subunits and two $57 \mathrm{kDa}$ proteins. Perhaps the mixture is random. However, the voltage-clamp studies suggest only a single functional species is represented on the surface.

The glycosidase studies must be interpreted with caution since 
it is difficult to determine whether the electrophoretic mobilities of both proteins are shifted with enzymatic treatment, that is, $59>57$ and $57>55$, or 57 is unaffected and $59>55 . N$-glycanase digestion produces species with mobilities of 58 and 55 $\mathrm{kDa}$, suggesting the $59 \mathrm{kDa}$ band is not simply converted to the $55 \mathrm{kDa}$ species by this enzyme. Regardless, these studies, in conjunction with the $\mathrm{N} 207 \mathrm{Q}$ mutation, do indicate that the mature Kv1.1 protcin contains posttranslational modifications other than N-linked glycosylation at Asn 207. However, high doses of tunicamycin result in synthesis of a single $55 \mathrm{kDa}$ core peptide, indicating this unknown processing step is in some way tunicamycin sensitive. Tunicamycin does inhibit palmitylation and phosphorylation (Schmidt and Catterall, 1987), making these processes good candidates for Kv1.1 modifications.

Is the Kv1.1 channel expression level controlled by protein degradation following synthesis? The levels of functional expression in the mouse L-cells (500-4000 per cell) mimic those found in native nerve and muscle (Karschin et al., 1991). The ability of these cells to synthesize transfected cell surface membrane proteins is not limited to this value since the $\mathrm{Na}^{+} / \mathrm{K}^{+}$ATPase (Takeyasu et al., 1987) is expressed in this system at levels up to $8 \times 10^{5}$ per L-cell. While not as high as those observed for actin, levels of channel mRNA are quite abundant (data not shown). Therefore, transcript availability is not a limiting factor. Some other mechanism must exist whereby channel expression is kept low. This finding is not unique to the L-cell system; whether stable or transient systems, mammalian or insect cells are used, functional expression levels rarely exceed those found in native tissues (Karschin et al., 1991). In fact, the greatest difficulty in the area of ion channel biochemistry is the fact that most cell systems do not produce channel densities beyond the physiological level of $1-2$ channels $/ \mu \mathrm{m}^{2}$ of surface membrane. Potential rate-limiting steps are the initiation and completion of translation, subunit assembly, intracellular transport, and degradation.

The short pulse-chase experiment shown in Figure 6 indicates that $\mathrm{Kvl} .1$ protein is not rapidly synthesized with the majority of protein then being degraded. Channel protein synthesized within the $7 \mathrm{~min}$ window is stable for at least the next $4 \mathrm{hr}$. However, longer pulse-chase experiments indicate that Kv1.1 degradation has a $t_{1 / 2}$ of approximately $5 \mathrm{hr}$. Both the mature 57 and $59 \mathrm{kDa}$ species were degraded with the same kinetics and turnover was unaffected by removal of glycosylation at Asn 207 (data not shown). The $5 \mathrm{hr}$ half-life for Kv1.1 is much shorter than that measured for the $\mathrm{Na}^{+} / \mathrm{K}^{+}$-ATPase expressed in these L-cells (40 hr; M. M. Tamkun, unpublished observations). It is intriguing to speculate that the shorter half-life for mature Kv1.1 is one mechanism by which channel expression is kept low.

Conclusion. The present study describes the biosynthesis and posttranslational processing of a voltage-gated $\mathrm{K}^{+}$channel in a heterologous expression system. Heteromeric subunit assembly is perhaps cotranslational. Glycosylation at the single extracellular $\mathrm{N}$-linked consensus site accounts for only one of several processing steps, and it is not required for subunit assembly, transport to the surface, protein stability, or channel function. Cell surface channels are represented by two molecular weight species, while the Kv1.1 channel in mouse brain appears as a single $80 \mathrm{kDa}$ species (Wang et al., 1993). It is possible that this differential processing between the L-cell system and brain has functionally significant consequences. This issue will require direct comparison of Kv1.1 biosynthesis, processing, and func- tion between this heterologous expression system and the channel in its native cellular environment.

\section{References}

Abeijon C, Hirschberg CB (1992) Topography of glycosylation reactions in the endoplasmic reticulum. Trends Biol Sci 17:32-36.

Atkinson NS, Robertson GA, Ganetzky B (1991) A component of calcium-activated potassium channels encoded by the Drosophila slo locus. Science 253:551-555.

Ausubel FM, Brent R, Kingston RE, Moore DD, Seidman JG, Smith JA, Struhl K, eds (1989) Current protocols in molecular biology. New York: Wiley.

Baumann A, Grupe A, Ackermann A, Pongs O (1988) Structure of the voltage-dependent potassium channel is highly conserved from Drosophila to vertebrate central nervous system. EMBO J 7:24572463.

Chandy KG (1991) Simplified gene nomenclature (letter). Nature 352: 26.

Christie MJ, Adelman JP, Douglass J, North RA (1989) Expression of a cloned rat brain potassium channel in Xenopus oocytes. Science 244:221-224.

Christie MJ, North RA, Osborne PB, Douglass J, Adelman JP (1990) Heteropolymeric potassium channels expressed in Xenopus oocytes from cloned subunits. Neuron 4:405-411.

Chung FZ, Wang CD, Potter PC, Venter JC, Fraser CM (1988) Sitedirected mutagenesis and continuous expression of human $\beta$-adrenergic receptors. J Biol Chem 263:4052-4055.

Covarrubias M, Wei A, Salkoff L (1991) Shaker, Shal, Shab, and Shaw express independent $\mathrm{K}^{+}$current systems. Neuron 7:763-773.

Fambrough DM, Bayne EK (1983) Multiple forms of $\left(\mathrm{Na}^{+}+\mathrm{K}^{+}\right)$ATPase in the chicken. Selective detection of the major nerve, skeletal muscle, and kidney form by a monoclonal antibody. J Biol Chem 258:3926-3935.

Frech GC, VanDongen AMJ, Schuster G, Brown AM, Joho RH (1989) A novel potassium channel with delayed rectifier properties isolated from rat brain by expression cloning. Nature 340:642-645.

Gilly WF, Lucero MT, Horrigan FT (1990) Control of the spatial distribution of sodium channels in giant fiber lobe neurons of the squid. Neuron 5:663-674.

Harrison NL, Radke HK, Tamkun MM, Lovinger DM (1993) Modulation of gating of cloned rat and human $\mathrm{K}^{+}$channels by micromolar $\mathrm{Zn}^{2+}$. Mol Pharmacol 43:482-486.

Heginbotham L, Abramson T, MacKinnon R (1992) A functional connection between the pores of distantly related ion channels as revealed by mutant $\mathrm{K}^{+}$channels. Science 258:1152-1155.

Ho K, Nichols CG, Lederer WJ, Lytton J, Vassilev PM, Kanazirska MV, Hebert SC (1993) Cloning and expression of an inwardly rectifying ATP-regulated potassium channel. Nature 362:31-38.

Hoshi T, Zagotta WN, Aldrich RW (1990) Biophysical and molecular mechanisms of Shaker potassium channel inactivation. Science 250: 533-538.

Isacoff EY, Jan YN, Jan LY (1990) Evidence for the formation of heteromultimeric potassium channels in Xenopus oocytes. Nature 345:530-534.

Karschin A, Aiyar J, Gouin A, Davidson N, Lester HA (1991) $\mathrm{K}^{+}$ channel expression in primary cell cultures mediated by Vaccinia virus. FEBS Lett 278:229-233.

Keller RK, Adair WL, Ness GC (1979) Studies on the regulation of glycoprotein biosynthesis. An investigation of the rate-limiting steps of dolichol phosphate biosynthesis. J Biol Chem 254:9966-9969.

Koren G, Liman ER, Logothetis DE, Nadal-Ginard B, Hess P (1990) Gating mechanisms of a cloned potassium channel expressed in frog oocytes and mammalian cells. Neuron 2:39-51.

Krieg PA, Melton DA (1987) An enhancer responsible for activating transcription at the midblastula transition in Xenopus development. Proc Natl Acad Sci USA 84:2331-2335.

Kubo Y, Baldwin TJ, Jan YN, Jan LY (1993) Primary structure and functional expression of a mouse inward rectifier potassium channel. Nature 362:127-132.

Li M, Jan YN, Jan LY (1992) Specification of subunit assembly by the hydrophilic amino-terminal domain of the Shaker potassium channel. Science 257:1225-1230. 
Liman ER, Tytgat J, Hess P (1992) Subunit stoichiometry of a mammalian $\mathrm{K}^{+}$channel determined by construction of multimeric cDNAs. Neuron 9:861-871.

MacKinnon R (1991) Determination of the subunit stoichiometry of a voltage-activated potassium channel. Nature 350:232-235.

MacKinnon R, Miller C (1989) Mutant potassium channels with altered binding of charybdotoxin, a pore-blocking peptide inhibitor. Science 245:1382-1385.

Marston FAO (1987) The purification of eukaryotic polypeptides expressed in Escherichia coli. In: Expression of cloned genes: a practical approach (Glover D, ed), pp 89-111. Oxford: IRL.

McCormack K, Lin L, Iverson LE, Tanouye MA, Sigworth FJ (1992) Tandem linkage of Shaker $\mathrm{K}^{+}$channel subunits does not ensure the stoichiometry of expressed channels. Biophys J 63:1406-1411.

$\mathrm{Ng}$ DT, Hiebert SW, Lamb RA (1990) Different roles of individual $\mathrm{N}$-linked oligosaccharide chains in folding, assembly, and transport of the simian virus 5 hemagglutinin-neuraminidase. Mol Cell Biol 10:1989-2001.

O'Shannessy DJ, Quarles RH (1985) Specific conjugation reactions of the oligosaccharide moieties of immunoglobulins. J Appl Biochem 7:347-355.

Papazian DM, Schwarz TL, Tempel BL, Jan YN, Jan LY (1987) Cloning of genomic and complementary DNA from Shaker, a putative potassium channel gene from Drosophila. Science 237:749-753.

Papazian DM, Timpe LC, Jan YN, Jan LY (1991) Alteration of voltage dependence of Shaker potassium channel by mutations in the $\mathrm{S} 4$ sequence. Nature 349:305-310.

Philipson LH, Miller RJ (1992) A small $\mathrm{K}^{+}$channel looms, large. Trends Pharm Sci 13:8-11.

Po SS, Snyders DJ, Baker R, Tamkun MM, Bennett PB (1992) Functional expression of an inactivating potassium channel cloned from human heart. Circ Res 71:732-736.

Po SS, Roberds SL, Snyders DJ, Tamkun MM, Bennett PB (1993) Heteromultimeric assembly of human potassium channels. Circ Res 72:1326-1336.

Pongs O, Kecskemethy N, Muller R, Krah-Jentgens I, Baumann A, Kiltz HH, Canal I, Llamazares S, Ferrus A (1988) Shaker encodes a family of putative potassium channel proteins in the nervous system of Drosophila. EMBO J 7:1087-1096.

Roberds SL, Tamkun MM (1991) Cloning and tissue-specific expression of five voltage-gated potassium channel cDNAs expressed in rat heart. Proc Natl Acad Sci USA 88:1798-1802.

Roberds SL, Knoth KM, Po S, Blair TA, Bennett PB, Hartshorne RP, Snyders DJ, Tamkun MM (1993) Molecular biology of the voltagegated potassium channels of the cardiovascular system. J Cardiovasc Electrophys 4:68-80.

Rosenberg RL, East JE (1992) Cell-free expression of functional Shaker potassium channels. Nature 360:166-169.

Ruppersberg JP, Schroter KH, Sakmann B, Stocker M, Sewing S, Pongs $O$ (1990) Heteromultimeric channels formed by rat brain potassium-channel proteins. Nature 345:535-537.

Rüther U, Müller-Hill B (1983) Easy identification of cDNA clones. EMBO J 2:1791-1794.
Schmidt JW, Catterall WA (1987) Palmitylation, sulfation, and glycosylation of the $\alpha$ subunit of the sodium channel. J Biol Chem 262: 13713-13723.

Stuhmer W, Ruppersberg JP, Schroter KH, Sakmann B, Stocker M, Giese KP, Perschke A, Baumann A, Pongs O (1989) Molecular basis of functional diversity of voltage-gated potassium channels in mammalian brain. EMBO J 8:3235-3244.

Swanson R, Marshall J, Smith JS, Williams JB, Boyle MB, Folander K, Luneau CJ, Antanavage J, Oliva C, Buhrow SA, Bennett C, Stein RB, Kaczmarek LK (1990) Cloning and expression of cDNA and genomic clones encoding three delayed rectifier potassium channels in rat brain. Neuron 4:929-939.

Takeyasu K, Tamkun MM, Siegel NR, Fambrough DM (1987) Expression of hybrid $\left(\mathrm{Na}^{+} / \mathrm{K}^{+}\right)$-ATPase activity expressed in mouse $\mathrm{L}$ cells by transfection with DNA encoding the $\alpha \beta$ subunit of an avian sodium pump. J Biol Chem 262:10733-10740.

Takumi T, Ohkubo H, Niakanishi S (1988) Cloning of a membrane protein that induces a slow voltage-gated potassium current. Science 242:1042-1045.

Tamkun MM, Fambrough DM (1986) The $\left(\mathrm{Na}^{+}+\mathrm{K}^{+}\right)$-ATPase of chick sensory neurons. J Biol Chem 261:1009-1019.

Tamkun MM, Knoth K, Walbridge J, Kroemer H, Roden D, Glover D (1991) Molecular cloning and characterization of two voltagegated $\mathrm{K}^{+}$channel cDNAs from human ventricle. FASEB J 5:331337.

Tempel BL, Papazian DM, Schwarz TL, Jan YN, Jan LY (1987) Sequence of a probable potassium channel component encoded at Shaker locus of Drosophila. Science 237:770-775.

Timpe LC, Schwartz TL, Tempel BL, Papazian DM, Jan YN, Jan LY (1988) Expression of functional potassium channels from Shaker cDNA in Xenopus oocytes. Nature 331:143-145.

Tseng-Crank JCL, Tseng G-N, Schwartz A, Tanouye MA (1990) Molecular cloning and functional expression of a potassium channel cDNA isolated from a rat cardiac library. FEBS Lett 268:63-68.

Van Koppen CJ, Nathanson NM (1990) Site-directed mutagenesis of the $\mathrm{m} 2$ muscarinic acetylcholine receptor. Analysis of the role of $N$-glycosylation in receptor expression and function. $\mathrm{J}$ Biol Chem 265:20887-20892.

Waechter CJ, Schmidt JW, Catterall WA (1983) Glycosylation is required for maintenance of functional sodium channels in neuroblastoma cells. J Biol Chem 258:5117-5123.

Warmke J, Drysdale R, Ganetzky B (1991) A distinct potassium channel polypeptide encoded by the Drosophila eag locus. Science 252: $1560-1562$.

Wang, H, Kunkel DD, Martin TM, Schwartzkroin PA, Tempel BL (1993) Heteromeric $\mathrm{K}^{+}$channels in terminal and juxtaparanodal regions of neurons. Nature 365:75-79.

Yool AJ, Schwartz TL (1991) Alteration of ionic selectivity of a $\mathrm{K}^{+}$ channel by mutation of the H5 region. Nature 349:700-704.

Zona D, Eusebi F, Miledi R (1990) Glycosylation is required for maintenance of functional voltage-activated channels in growing neocortical neurons of the rat. Proc R Soc Lond [Biol] 239:1 19-127. 